\title{
Using Tourist Typologies for Ecotourism Research
}

\author{
Glen T. Hvenegaard \\ Department of Geography, Augustana University College, 4901-46 Avenue, \\ Camrose, Alberta T4V 2R3, Canada
}

Research to identify ecotourists or segment ecotourists from other tourist types has not occurred in a consistent manner, reducing potential comparability to studies at other times and places. Ecotourists have been identified using a variety of techniques, broadly categorised as tourist typologies that are cognitive-normative and interactional. This paper tests the level of congruency among four versions of these tourist typologies (ie. researcher-based,respondent-based, activity-based, and motivation-based), using a case study from a national park in northern Thailand. Based on the considerable consistency found, several pragmatic conclusions are presented.

\section{Introduction}

As refinements are made to the definitions and conceptual frameworks for ecotourism (e.g. Björk, 2000; Blamey, 1997; Diamantis \& Ladkin, 1999; Hvenegaard, 1994), a major problem in ecotourism research remains. Research to identify ecotourists or segment ecotourists from other tourist types has not occurred in a consistent manner. It is necessary to include situation-specific information in this process, but this may lead to results that are not comparable with studies at other times and places. Such comparability is necessary to generalise about studies that deal with important ecotourism issues such as environmental impacts (Blane \& Jaakson, 1994), community impacts (Lindberg et al., 1996), conservation involvement (Hvenegaard \& Dearden, 1998), motivations (Eagles, 1992), and demographics (Eagles \& Cascagnette, 1995).

Attempts to define tourist types have also been called segmentation, classification, and clustering. Identifying distinct tourist types is beneficial for the planning, management, and marketing of tourism (Smith \& Smale, 1980; Taylor, 1986). Tourist typology information allows managers to address different motivations, experiences, and impacts of tourist types (Diamantis, 1998; Eagles, 1992) and to understand which tourist types are more likely to be found at different stages in the evolution of tourism areas (Duffus \& Dearden, 1990). Moreover, in terms of sustainability, it is necessary to use a tourism typology to match tourism types to resource capabilities (Wall, 1993).

A variety of techniques are available to identify ecotourists or to distinguish ecotourists from other tourist types (Blamey, 1997; Bottrill \& Pearce, 1995). For example, many studies consider tourists entering a particular site to be ecotourists (e.g. Lindberg et al., 1996; Tobias \& Mendelsohn, 1991). Other studies consider all tourists engaging in particular activities (Ceballos-Lascurain, 1991) or participating in certain tours to be ecotourists (e.g. Diamantis, 1998; Eagles, 1992). Some studies use both site and activity criteria (e.g. Wall, 1994). 
Only a few studies use motivational information to identify ecotourists. For example, Ballantine and Eagles (1994) define ecotourists as respondents who:

- answer 'very important' or 'somewhat important' to 'learning about nature' as a motivation when planning a trip; and

- answer 'very important' or 'somewhat important' to 'wilderness/undisturbed areas' as an attraction when choosing a trip; and

- must spend at least one-third of their vacation on 'safari' or equivalent ecotourism activities.

As well, Boo (1990) classified nature tourists according to the importance they placed on protected areas for choosing a country as a destination (i.e. primary, important, somewhat, and not). Other researchers segment ecotourists using travel benefits (Palacio \& McCool, 1997), social values (Blamey \& Braithwaite, 1997), or the new environmental paradigm (Luzar et al., 1998). Some researchers go further to distinguish sub-types of ecotourists. For example, Laarman and Durst (1987) used interest level and the degree of physical rigour to distinguish between hard and soft nature tourists.

Some of these tourist typologies are theoretical in nature, and some have been empirically tested. Most rely heavily on the researchers' observations and judgement of tourist activities or sites visited to designate a tourist as an ecotourist. Fewer studies use motivations to assist in this designation. Finally, very few studies have asked the respondents, who know their own activities and motivations the best, to classify themselves.

Given the lack of consistency in identifying ecotourists, it is unknown whether ecotourists identified in one study would also be identified in another study using different methods. Thus, this paper examines the conceptual basis for tourist typologies and identifies four main methods of applying these tourist typologies. Next, based on a case study, the paper tests for differences among these typologies at the same site. Last, the practical implications of the results are explored.

\section{Tourist Typologies}

Conceptually, Murphy (1985) identifies two general categories of tourist typologies, interactional and cognitive-normative. Lowyck et al. (1992) make a similar distinction between typologies of the tourist per se, and the typologies of tourist lifestyles. First, interactional tourist typologies are primarily based on the interactions between the tourists and the destination area (although Healy (1992) suggests a typology for tourist destinations alone). For example, Cohen (1972) proposes a four-part tourist typology, based on the tourist's desire for familiarity and the level of institutionalisation preferred (later tested by Keng \& Cheng, 1999). The dimensions of Smith's (1977) tourist typology are similar, but more detailed. Other similar interactional tourist typologies have been based on trip indices (Uysal \& McDonald, 1989), travel behaviours, interests, and opinions (Perreault et al., 1977). Interactional typologies have also been identified on a regional (Ditton et al., 1975) or site basis (Collins \& Hodge, 1984). Interactional tourist typologies are used in ecotourism studies which identify ecotourists based on activities (e.g. Eagles, 1992).

Second, cognitive-normative tourist typologies focus on the travel motiva- 
tions of tourists. For example, Plog's (1972; later tested by Smith, 1990) typology recognises allocentrics (adventuresome, individual travel), mid-centrics (individual travel to destinations with facilities), and psychocentrics (packaged holidays to popular destinations), depending on how tourists conform to societal or individual desires. Cohen (1979) refers to a tourist's motivations, based on a spiritual center, where tourists seek travel for existential, experimental, experiential, diversionary, or recreational reasons. Cognitive-normative typologies have also been applied to more specific outdoor user groups (e.g. snowmobilers; May et al., 2001). Information needed to develop cognitive-normative typologies usually comes from interviews, but occasionally by self-designation (Kaynak \& Yavas, 1981). Cognitive-normative typologies have been used to identify ecotourists on the basis of their motivations (e.g. Ballantine \& Eagles, 1994), attitudes (e.g. Luzar et al., 1998), and values (e.g. Blamey \& Braithwaite, 1997).

There are several criticisms of tourist typologies. First, many tourist typologies are tautological. That is, generalisations from a typology are restricted to the data that created the typology (Lowyck et al., 1992). Second, without methodological consistency, the names chosen for tourist categories vary widely and strongly reflect the researcher's point of view (Sharpley, 1994). Third, without extensive case studies, the use of questionnaires, the most common method of gathering typology data, is problematic (Lowyck et al., 1992). Fourth, tourists' motivations and activities may be too complex to collapse into rigid categories (Lowyck et al., 1992). For example, features that attract tourists to a site can be considered motivations, but when acted upon, considered activities (e.g. Moscardo et al., 2000). Fifth, most typologies are static and cannot model the evolution of tourist types over time (Sharpley, 1994), and therefore typologies have limited predictability. Nevertheless, Shoemaker (2000) has shown that markets among mature tourists remained relatively stable over a 10-year period. Finally, most typologies are theoretical in nature, and just a few have been empirically tested. Pearce (1985) argues that it is necessary to interrelate tourist roles to assess their similarities and differences.

Despite the limitations of tourist typologies, they are widely used to segment tourist populations. Moreover, given their conceptual basis, there is much potential overlap between the interactional and cognitive-normative approaches, but this overlap has not been tested in ecotourism setting. Specifically, this paper tests for differences between these approaches, represented by four discrete typologies (researcher-based, respondent-based, activity-based, and motivation-based), using a single case study from northern Thailand.

\section{Country and Site}

Thailand's tourism industry has grown rapidly in recent years. About 9.6 million foreigners visited the country in 2000, a 10.7\% increase from 1999 (Tourism Authority of Thailand, 2001). The Tourism Authority of Thailand's (1997) recent Ecotourism Strategy seeks to promote ecotourism and to enhance management of the industry. Most ecotourism research in Thailand has focused on the national parks and other protected areas, which received more than 11.5 million visits in 1994 (National Parks Division, 1995), up from about 4 million visits in 1985 (Brockelman, 1988). Chudintra (1993) assumes that all visitors to 
national parks are ecotourists, but activities and motivations of park visitors vary widely. A small and growing proportion of the visitors have a focus on wildlife viewing activities that are commonly associated with ecotourism (Durst, 1986; Elliott, 1993). Another significant proportion participate in hilltribe trekking (Dearden, 1991). Such activities are exemplified in Doi Inthanon National Park (DINP).

DINP, a national park since 1972, is located in northwestern Thailand, about $80 \mathrm{~km}$ southwest of Chiang Mai. Chiang Mai is the second largest city in Thailand and major tourism centre of the North. DINP is one of the most popular parks in the country, with visitation increasing from 312,779 visitors in 1983 (Kasetsart University, 1989) to 935,641 visitors in 1993 (DINP, 1993). DINP has a paved road to the summit, campground, day use areas, rental bungalows, several restaurants, and three visitor centres. There are many attractions, including wildlife, highest summit in Thailand, waterfalls, walking trails, scenic overlooks, chedis (religious shrines honouring the King and Queen), caves, the cool climate, and hilltribe people.

\section{Methodology}

From November, 1993 to March, 1994, Thai- and English-speaking interviewers randomly selected and interviewed birders and general park visitors at sites in DINP. Trekkers were interviewed after their DINP trips at trekking companies in Chiang Mai. Self-administered questionnaires were also used for birders visiting the Doi Inthanon Bird Centre, a privately-owned restaurant and informal gathering centre for birders. Respondents were asked, among other items, about their motivations and trip activities. Data were analysed with the Statistical Package for the Social Sciences.

Four tourist typologies were considered. First, an interactional typology was based on primary activities; this typology was researcher-based because the tourist types were defined by the researcher before collecting information. Visitors who participated in guided hilltribe treks were called trekkers. Visitors who visibly participated in birding activities (based on clues such as visiting popular birding sites and using binoculars, spotting scopes, and bird books), were called birders. The remaining visitors, who participated in a wide variety of other activities, were called general visitors.

The second typology, a variant of both interactional and cognitive-normative typologies, was respondent-based, in that respondents categorised themselves, by choosing from a predetermined list of options. Respondents were asked, 'On this trip to the park, which term would best describe yourself?' The list of options was assembled from discussions with tourists, pretests, and from other studies (see Cohen, 1972; Harron, 1991; Hvenegaard, 1994).

Third, an interactional typology was activity-based, in that places visited and tourist activities were the primary inputs. This typology used dichotomous variables based on visiting (or not visiting) 19 selected sites in the park and participating (or not participating) in three selected activities (watched wildlife, walked on the trails, or stayed more than one day in the park). K-Means cluster analysis stopped before one of the clusters fell below $5 \%$ of the total sample. The first few cases in the sample provided initial cluster centres, and were updated in an itera- 
tive process to minimise Euclidean distance from each case to the cluster centre. Iterations ceased if any change in a cluster centre was less than $2 \%$ of the minimum distance between initial centres.

Fourth, a cognitive-normative typology was motivation-based. Respondents were asked an open-ended question: 'What was your main reason for visiting the park?'

\section{Results}

\section{Researcher-based typology}

Of 935,641 visits in 1993, for this interactional typology, an estimated 723 were from birders, 7967 from trekkers, and the remainder from general visitors. We collected questionnaires from 137 birders, 211 trekkers, and 509 general visitors, with an overall response rate of $92 \%$. For background, birders visited an average of 6.6 park sites, compared to 2.0 for trekkers, and 4.2 for general visitors $(F=$ $324.3, \mathrm{df}=2, p=0.0000)$. Birders had more opportunities to visit park sites because they stayed longer (3.2 days), on average, than either trekkers (1.0 days) or general visitors (1.1 days; $F=564.3, \mathrm{df}=2, p=0.0000)$.

\section{Respondent-based typology}

Six options were chosen to represent this typology (Table 1). Common responses in the 'other' option included part of a study group, national park enthusiast, motorbiker, Buddha worshipper, and people on business. These results were strongly correlated with the researcher-based typology. Reading the columns, most birders considered themselves as either bird watchers or eco/nature tourists. Most trekkers considered themselves as travellers or general tourists; these proportions are similar to those found by Harron (1991). Surprisingly, few trekkers considered themselves as trekkers or hikers, even though they were currently on a hilltribe trek. Most general visitors considered themselves as general tourists, but smaller segments considered themselves eco/nature tourists or travellers.

Table 1 Comparison of researcher-based and respondent-based tourist typologies*

\begin{tabular}{|c|c|c|c|}
\hline \multirow[t]{3}{*}{ Respondent-based typology } & \multicolumn{3}{|c|}{ Researcher-based typology } \\
\hline & Birder & Trekker & General visitor \\
\hline & \multicolumn{3}{|c|}{ Percentage of group choosing } \\
\hline Ecotourist or nature tourist & 22.3 & 10.7 & 12.6 \\
\hline Bird watcher & 63.8 & 0.8 & 0.0 \\
\hline Traveller & 3.8 & 54.2 & 14.2 \\
\hline Trekker or hiker & 2.3 & 11.5 & 0.6 \\
\hline General tourist & 4.6 & 22.1 & 68.1 \\
\hline Other & 3.1 & 0.8 & 4.4 \\
\hline Total & 100.0 & 100.0 & 100.0 \\
\hline
\end{tabular}

* Statistics: $\chi^{2}=665.2 ; \mathrm{df}=10 ; p=0.0000$ based on cross-tabulation of expected and actual values; however, $22 \%$ of the cells had expected frequencies less than 5 , leaving the potential for bias. 


\section{Activity-based typology}

For this interactional typology, cluster analysis revealed five groups (Table 2). Labels for each cluster were based on dominant activity patterns. Highlights trekkers visited only two sites, as chosen by the trekking guides and companies (one site, a remote waterfall, usually is visited only by trekking companies). Very few highlights trekkers, intensive visitors, or highlights visitors watched wildlife, walked on the trails, or stayed an extra day in the park. However, intensive visitors visited more sites (e.g. summit, hilltribe village, waterfall, and chedis) than highlights visitors (usually the summit and chedis). Almost all knowledgeable and generalist birders watched wildlife, walked on trails, and spent more than a day in the park. Knowledgeable birders visited fewer sites (usually a waterfall, several trails, the park headquarters, and the summit) than generalist birders, but these sites represent the best birding locations in the park. Generalist birders visited more information centres and far fewer birding locations than knowledgeable birders. The birder labels are chosen to reflect how much knowledge birders have (e.g. existence of productive birding sites) or desire (e.g. visits to information centres).

Table 2 Summary of variables used for activity-based tourist typology

\begin{tabular}{|c|c|c|c|c|c|}
\hline \multirow[t]{2}{*}{ Variables } & \multicolumn{5}{|c|}{ Activity cluster } \\
\hline & $\begin{array}{c}\text { Highlights } \\
\text { trekker }\end{array}$ & $\begin{array}{c}\text { Intensive } \\
\text { visitor }\end{array}$ & \begin{tabular}{|c|} 
Highlights \\
visitor
\end{tabular} & $\begin{array}{c}\text { Knowledgeable } \\
\text { birder }\end{array}$ & $\begin{array}{c}\text { Generalist } \\
\text { birder }\end{array}$ \\
\hline $\begin{array}{l}\text { Average number of sites } \\
\text { visited }\end{array}$ & 2.0 & 5.6 & 2.9 & 6.0 & 7.6 \\
\hline $\begin{array}{l}\text { Watched birds or other } \\
\text { wildlife }(\%)\end{array}$ & 35.2 & 32.5 & 32.5 & 100.0 & 97.1 \\
\hline Walked on forest trails (\%) & 0.0 & 9.6 & 15.9 & 100.0 & 94.3 \\
\hline $\begin{array}{l}\text { Spent more than one day } \\
\text { in the park }(\%)\end{array}$ & 0.0 & 7.7 & 3.2 & 95.1 & 91.4 \\
\hline
\end{tabular}

Each activity-based cluster closely aligned itself, with minor exceptions, with one of the researcher-based tourist types (Table 3). There was also considerable overlap with the respondent-based tourist typology (Table 4). Respondents calling themselves ecotourists or nature tourists had a variety of activity patterns, but were most similar to generalist birders. Self-described bird watchers were most similar to knowledgeable or generalist birders, travellers and trekkers or hikers were most similar to highlights trekkers, and general tourists were most similar to intensive and highlights visitors.

Table 3 Comparison of researcher-based and activity-based tourist typologies*

\begin{tabular}{|c|c|c|c|}
\hline \multirow[t]{3}{*}{ Activity-based typology } & \multicolumn{3}{|c|}{ Researcher-based typology } \\
\hline & Birder & Trekker & General visitor \\
\hline & \multicolumn{3}{|c|}{ Percentage of group in cluster } \\
\hline Highlights trekker & 0.0 & 100.0 & 0.0 \\
\hline Intensive visitor & 2.6 & 0.0 & 41.0 \\
\hline Highlights visitor & 3.5 & 0.0 & 54.4 \\
\hline Knowledgeable birder & 53.0 & 0.0 & 0.0 \\
\hline Generalist birder & 40.9 & 0.0 & 4.6 \\
\hline Total & 100.0 & 100.0 & 100.0 \\
\hline
\end{tabular}

* Statistics: $\chi^{2}=1456 . ; \mathrm{df}=8 ; p=0.0000$ based on cross-tabulation of expected and actual values. 
Table 4 Comparison of respondent-based and activity-based tourist typologies*

\begin{tabular}{||l|c|c|c|c|c||}
\hline \multirow{2}{*}{$\begin{array}{l}\text { Respondent-based } \\
\text { typology }\end{array}$} & \multicolumn{5}{|c||}{ Activity-based typology } \\
\cline { 2 - 6 } & $\begin{array}{c}\text { Highlights } \\
\text { trekker }\end{array}$ & $\begin{array}{c}\text { Intensive } \\
\text { visitor }\end{array}$ & $\begin{array}{c}\text { Highlights } \\
\text { visitor }\end{array}$ & $\begin{array}{c}\text { Knowledgeable } \\
\text { birder }\end{array}$ & $\begin{array}{c}\text { Generalist } \\
\text { birder }\end{array}$ \\
\cline { 2 - 7 } & \multicolumn{5}{|c|}{ Percentage of group choosing } \\
\hline $\begin{array}{l}\text { Ecotourist or nature } \\
\text { tourist }\end{array}$ & 10.7 & 18.4 & 7.4 & 15.0 & 30.9 \\
\hline Bird watcher & 0.8 & 0.0 & 0.7 & 78.3 & 30.9 \\
\hline Traveller & 54.2 & 13.5 & 13.4 & 1.7 & 14.7 \\
\hline Trekker or hiker & 11.5 & 1.4 & 0.4 & 0.0 & 2.9 \\
\hline General tourist & 22.1 & 61.4 & 74.7 & 1.7 & 16.2 \\
\hline Other & 0.8 & 5.3 & 3.3 & 3.3 & 4.4 \\
\hline Total & 100.0 & 100.0 & 100.0 & 100.0 & 100.0 \\
\hline
\end{tabular}

* Statistics: $\chi^{2}=651.7 ; \mathrm{df}=20 ; p=0.0000$ based on cross-tabulation of actual and expected values.

\section{Motivation-based typology}

Respondents listed 27 different motivations; similar motivations were lumped together, resulting in 9 categories. As expected, motivations were strongly correlated with the researcher-based typology (Table 5). Not surprisingly, birders were motivated primarily by birds and wildlife. Trekkers were motivated by a variety of attractions, but mostly culture and the hilltribes. General visitors also had a variety of motivations, but were dominated by scenery, waterfalls, and the highest point in Thailand.

Table 5 Comparison of researcher-based and motivation-based tourist typologies*

\begin{tabular}{|c|c|c|c|}
\hline \multirow[t]{3}{*}{ Motivation-based typology } & \multicolumn{3}{|c|}{ Researcher-based typology } \\
\hline & Birder & Trekker & General visitor \\
\hline & \multicolumn{3}{|c|}{ Percentage of group choosing } \\
\hline Highest point of Thailand & 0.7 & 0.0 & 24.0 \\
\hline Birds and wildlife & 80.9 & 0.5 & 3.8 \\
\hline Scenery and waterfalls & 1.5 & 18.1 & 33.5 \\
\hline Culture and hilltribes & 0.0 & 34.3 & 2.6 \\
\hline Social outing & 1.5 & 2.9 & 13.4 \\
\hline Natural environment & 13.2 & 11.4 & 9.6 \\
\hline Vacation & 0.7 & 11.4 & 6.4 \\
\hline Physical activity and adventure & 0.0 & 11.0 & 0.0 \\
\hline Other & 1.5 & 10.5 & 6.6 \\
\hline Total & 100.0 & 100.0 & 100.0 \\
\hline
\end{tabular}

* Statistics: $\chi^{2}=870.5 ; \mathrm{df}=16 ; p=0.0000$ based on cross-tabulation of expected and actual values.

There was also overlap with the respondent-based typology (Table 6). Self-described ecotourists or nature tourists were motivated by the natural environment, birds, wildlife, scenery, and waterfalls. Birders were motivated exclusively by birds and wildlife. Travellers had a variety of motivations. Trekkers or hikers were motivated primarily by culture and hilltribes. Finally, the motiva- 
Table 6 Comparison of motivation-based and respondent-based tourist typologies*

\begin{tabular}{|c|c|c|c|c|c|c|}
\hline \multirow{3}{*}{$\begin{array}{l}\text { Motivation-based } \\
\text { typology }\end{array}$} & \multicolumn{6}{|c|}{ Respondent-based typology } \\
\hline & $\begin{array}{c}\text { Ecotourist } \\
\text { or nature } \\
\text { tourist }\end{array}$ & $\begin{array}{c}\text { Bird } \\
\text { watcher }\end{array}$ & Traveller & $\begin{array}{l}\text { Trekker } \\
\text { or hiker }\end{array}$ & $\begin{array}{c}\text { General } \\
\text { tourist }\end{array}$ & Other \\
\hline & \multicolumn{6}{|c|}{ Percentage of group in cluster } \\
\hline $\begin{array}{l}\text { Highest point of } \\
\text { Thailand }\end{array}$ & 4.8 & 0.0 & 15.1 & 0.0 & 23.2 & 22.2 \\
\hline Birds and wildlife & 21.0 & 97.6 & 4.1 & 0.0 & 2.7 & 14.8 \\
\hline Scenery and waterfalls & 21.9 & 0.0 & 20.5 & 19.0 & 36.3 & 7.4 \\
\hline Culture and hilltribes & 4.8 & 0.0 & 16.4 & 38.1 & 4.6 & 18.5 \\
\hline Social outing & 5.7 & 0.0 & 5.5 & 0.0 & 15.2 & 7.4 \\
\hline Natural environment & 32.4 & 2.4 & 13.0 & 9.5 & 5.4 & 11.1 \\
\hline Vacation & 3.8 & 0.0 & 11.6 & 9.5 & 6.2 & 0.0 \\
\hline $\begin{array}{l}\text { Physical activity and } \\
\text { adventure }\end{array}$ & 0.0 & 0.0 & 4.1 & 14.3 & 0.5 & 3.7 \\
\hline Other & 5.7 & 0.0 & 9.6 & 9.5 & 5.4 & 14.8 \\
\hline Total & 100.0 & 100.0 & 100.0 & 100.0 & 100.0 & 100.0 \\
\hline
\end{tabular}

* Statisctics: $\chi^{2}=682.4 ; \mathrm{df}=40 ; p=0.0000$ based on cross-tabulation of expected and actual values.

tions of general tourists were varied, but concentrated on scenery, waterfalls, and the highest point of Thailand.

Last, this typology also overlapped the activity-based typology (Table 7). Highlights trekkers were primarily motivated by culture and the hilltribes, with various other interests. Intensive and highlights visitors were primarily motivated by scenery, waterfalls, and the highest point. Knowled geable birders were overwhelmingly motivated by birds and wildlife. Generalist birders were motivated by birds, wildlife, and the natural environment.

Table 7 Comparison of motivation-based and activity-based tourist typologies*

\begin{tabular}{||l|r|r|r|r|r|r||}
\hline \multirow{3}{*}{ Motivation-based typology } & \multicolumn{5}{|c|}{ Activity-based typology } \\
\cline { 2 - 6 } & $\begin{array}{c}\text { Highlights } \\
\text { trekker }\end{array}$ & $\begin{array}{c}\text { Intensive } \\
\text { visitor }\end{array}$ & $\begin{array}{c}\text { Highlights } \\
\text { visitor }\end{array}$ & $\begin{array}{c}\text { Knowledgeable } \\
\text { birder }\end{array}$ & $\begin{array}{c}\text { Generalist } \\
\text { birder }\end{array}$ \\
\cline { 2 - 7 } & \multicolumn{5}{|c|}{ Percentage of group in cluster } \\
\hline Highest point of Thailand & 0.0 & 19.9 & 27.7 & 1.6 & 1.4 \\
\hline Birds and wildlife & 0.5 & 6.8 & 3.3 & 91.8 & 49.3 \\
\hline Scenery and waterfalls & 18.2 & 33.5 & 32.8 & 1.6 & 14.5 \\
\hline Culture and hilltribes & 34.4 & 2.9 & 2.2 & 0.0 & 1.4 \\
\hline Social outing & 2.9 & 11.2 & 15.5 & 1.6 & 4.3 \\
\hline Natural environment & 11.5 & 13.1 & 6.6 & 3.3 & 20.3 \\
\hline Vacation & 11.5 & 6.36 & 4.8 & 0.0 & 7.2 \\
\hline $\begin{array}{l}\text { Physical activity and } \\
\text { adventure }\end{array}$ & 11.0 & 0.0 & 0.0 & 0.0 & 0.0 \\
\hline Other & 10.0 & 6.3 & 7.0 & 0.0 & 1.4 \\
\hline
\end{tabular}

* Statistics: $\chi^{2}=785.8 ; \mathrm{df}=32 ; p=0.0000$ based on cross-tabulation of expected and actual values. 


\section{Discussion}

Murphy (1985) argued that both cognitive-normative and interactional typologies are relevant, since tourist choices of activities and destinations (i.e. interactional) relate to, and result from, tourist motivations (i.e. cognitive-normative). Using four different tourist typologies, this study has shown that there are consistent interrelationships among activities, motivations, and perceptions of tourist type (chosen by the researcher or the respondent). Three specific results deserve further explanation.

First, these analyses have shown a high level of congruence between interactional and cognitive-normative typologies. This is best illustrated by comparing the activity-based typology (most representative of the interactional category) with the motivation-based typology (most representative of the cognitive-normative category; Table 7). For this study group, motivations seem to reflect consistent patterns of activities and sites visited. Of course, researchers should expect, and have long shown, that motivations and activities are reasonably consistent. However, it is useful to show this when they form the basis of distinct tourist typologies.

Second, most consistency is shown among the researcher-based, respondent-based, and activity-based typologies. The motivation-based typology produces less distinct patterns (Tables 5,6 and 7 ), partly because the wide variety of responses cannot be conveniently collapsed into just a few categories. Moreover, tourists rarely travel for simplistic reasons; assessments of motivations usually point to complex and dynamic reasons for tourist behaviour (May et al., 2001; Orams, 2000). In other studies, substantial differences in motivations exist between ecotourists and general tourists (Eagles, 1992). However, the satisfactions of ecotourists, such as whale watchers, are influenced by a wide variety of factors (Orams, 2000).

Third, researcher-based and respondent-based typologies are strongly related. This is significant because most studies use a researcher-based typology of some sort, based on the assumption that researchers can simplify the complex set of motivations and activities representing each respondent. While not perfect, in this study, researchers' decisions about tourist types closely resembles the respondents' decisions, especially the birder and general visitor tourist types (Table 1). Nevertheless, respondents' ideas about, and motivations for, ecotourism experiences can vary widely, as shown in an Australian case study (Chirgwin \& Hughes, 1997).

The limitations outlined by Lowyck et al. (1992) and Sharpley (1994) apply to this study. There were many arbitrary methodological decisions about identifying differentiating activities, collapsing and labelling categories, and determining the number of clusters. In addition, since this case study represents a set of tourist types not found in other tourist destinations, generalisations should be made cautiously. The tourist typologies are also constrained by time and space; at other times and in other places, the typologies may change. However, for one tourist group, Shoemaker (2000) showed some consistency among market segments over time.

Nevertheless, the existing overlap suggests that, based on the variables collected, these tourist types may approximate true groups in the population, 
each with distinct characteristics. If so, inconsistent methods to identify ecotourists may not be such a severe problem. Some typologies could serve as useful indicators of the others. This confirms Murphy's (1985:5) assertion about the 'strong links between visitor expectations-motivations and the structure of destination areas'.

In practice, then, one or more of these typologies could be applied whenever advantageous to the research situation. As well, the overlap can be considered in light of various research needs. For example, the need to reduce research costs may dictate the use of less expensive techniques such as the researcher-based typology (where costs are reduced by simply observing activities to determine a tourist type). In other cases, if motivation information is collected for other reasons (e.g. to assist in interpreting attitudes and behaviours), a subsequent tourist typology could be generated. Even though collecting information for the activity-based typology is time-consuming, trends about activities and sites visited are very useful to site managers. The respondent-based typology may require further research since it is based on tourists' varying understanding of, and personal identity with, a number of different tourist types.

Additional research is needed to clarify potential applications of tourist typologies. First, more case studies for other ecotourist groups and locations are needed to test the extent to which the congruence exists between interactional and cognitive-normative tourist typologies (i.e. the correlation between attitudes-motivations and behaviours; Mo et al., 1993). Second, researchers should examine the multi-dimensional aspects of tourism typologies (Sharpley, 1994), using a variety of other statistical analyses (e.g. Hvenegaard \& Dearden, 1998; Pearce, 1985). Third, research should assess how motivations change from the time of the original decision to travel to the time of actual activity. Finally, tourist typologies should be examined across various tourism situations for predicting tourist behaviour (Sharpley, 1994), such as economic and environmental impacts, and tourist attitudes and preferences.

\section{Acknowledgements}

Support for this research was provided by the International Development Research Centre and the Canada-ASEAN Centre. The help of research assistants and staff of DINP was also indispensable. Thanks are due to two anonymous reviewers for their useful comments.

\section{Correspondence}

Any correspondence should be directed to Dr Glen T. Hvengaard, Department of Geography, Augustana University College, 4901-46 Avenue, Camrose, Alberta T4V 2R3, Canada (hveng@augustana.ca).

\section{References}

Ballantine, J.L. and Eagles, P.F.J. (1994) Defining Canadian ecotourists. Journal of Sustainable Tourism 2 (1), 1-6.

Björk, P. (2000) Ecotourism from a conceptual perspective, an extended definition of a unique tourism form. International Journal of Tourism Research 2, 189-202.

Blamey, R.K. (1997) Ecotourism: The search for an operational definition. Journal of Sustainable Tourism 5 (2), 109-130. 
Blamey, R.K. and Braithwaite, V.A. (1997) A social values segmentation of the potential ecotourism market. Journal of Sustainable Tourism 5 (1), 29-45

Blane, J.M. and Jaakson, R. (1994) The impact of ecotourism boats on the St. Lawrence Beluga whales. Environmental Conservation 21 (3), 267-269.

Boo, E. (1990) Ecotourism: The Potentials and Pitfalls. Washington, DC: World Wildlife Fund.

Bottrill, C.G. and Pearce, D.G. (1995) Ecotourism: Towards a key elements approach to operationalising the concept. Journal of Sustainable Tourism 3 (1), 45-54.

Brockelman, W. (1988) Nature conservation. In A. Arbhabhirama, D. Phantumvanit, J. Elkington and P. Ingkasuwan (eds) Thailand Natural Resource Profile (pp. 179-237). Singapore: Oxford University Press.

Ceballos-Lascurain, H. (1991) Tourism, ecotourism and protected areas. Parks 2 (3),31-35.

Chirgwin, S. and Hughes, K. (1997) Ecotourism: The participants' perceptions. The Journal of Tourism Studies 8 (2), 2-7.

Chudintra, S. (1993) Nature tourism profile: Thailand. In J. Nenon and P.B. Durst (eds) Nature Tourism in Asia: Opportunities and Constraints for Conservation and Economic Development (pp. 31-41). Washington, DC: USDA Forest Service.

Cohen, E. (1972) Toward a sociology of international tourism. Social Research 39, 164-172.

Cohen, E. (1979) A phenomenology of tourist experiences. Sociology 13, 179-202.

Collins, R. and Hodge, I. (1984) Clustering visitors for recreation management. Journal of Environmental Management 19, 147-158.

Dearden, P. (1991) Tourism and sustainable development in northern Thailand. The Geographical Review 81 (4), 400-413.

Diamantis, D. (1998) Consumer behaviour and ecotourism products. Annals of Tourism Research 25, 515-518.

Diamantis, D. and Ladkin, A. (1999) The links between sustainable tourism and ecotourism: A definitional and operational perspective. The Journal of Tourism Studies $10(2), 35-45$.

Ditton, R.B., Goodale, T.L. and Johnsen, P.K. (1975) A cluster analysis of activity, frequency, and environment variables to identify water-based recreation types. Journal of Leisure Research 7 (4), 282-295.

Doi Inthanon National Park (1993) 1993 Annual Report of Doi Inthanon National Park. Chiang Mai, Thailand: Doi Inthanon National Park.

Duffus, D.A. and Dearden, P. (1990) Non-consumptive wildlife-oriented recreation: A conceptual framework. Biological Conservation 53, 213-231.

Durst, P.B. (1986) Natural History and Nature-Oriented Adventure Travel For Rural Development and Wildlands Management: Diagnosis of Research Needs and Project Opportunities for Thailand. FPEI Working Paper No. 12, Research Triangle Park, NC: Southeastern Center for Forest Economics Research.

Eagles, P.F.J. (1992) The travel motivations of Canadian ecotourists. Journal of Travel Research 31 (2), 3-7.

Eagles, P.F.J. and Cascagnette, J.W. (1995) Canadian ecotourists: Who are they? Tourism Recreation Research 20 (1), 22-28.

Elliott, S. (1993) Tourists' perceptions of wildlife and national parks in northern Thailand. Journal of Wildife in Thailand 3, 43-50.

Harron, S. (1991) Trekking among the Hilltribes of Northern Thailand: Analyzing an alternative tourism market. MA Thesis, University of Victoria.

Healy, R.G. (1992) The role of tourism in sustainable development. Paper presented at the 4th World Congress on National Parks and Protected Areas. Caracas, Venezuela.

Hvenegaard, G.T. (1994) Ecotourism: A status report and conceptual framework. The Journal of Tourism Studies 5 (2), 24-35.

Hvenegaard, G.T. and Dearden, P. (1998) Ecotourism versus tourism in a Thai national park. Annals of Tourism Research 25 (3), 700-720.

Kasetsart University (1989) The Master Plan of Doi Inthanon National Park. Bangkok: Kasetsart University.

Kaynak, E. and Yavas, U. (1981) Segmenting the tourism market by purpose of trip. International Journal of Tourism Management 2 (2), 105-112. 
Keng, K.A. and Cheng, J.L.L. (1999) Determining tourist role typologies: An exploratory study of Singapore vacationers. Journal of Travel Research 37, 382-390.

Laarman, J.G. and Durst, P.B. (1987) Nature travel in the tropics. Journal of Forestry 85 (5), 43-46.

Lindberg, K., Enriquez, J. and Sproule, K. (1996) Ecotourism questioned: Case studies from Belize. Annals of Tourism Research 23, 543-562.

Lowyck, E., Van Langenhove, L. and Bollaert, L. (1992) Typologies of tourist roles. In P. Johnson and B. Thomas (eds) Choice and Demand in Tourism (pp. 13-32). London: Mansell Publishing.

Luzar, E.J., Diagne, A., Gan, C.E.C. and Henning, B.R. (1998) Profiling the nature-based tourist: A multinomial logit approach. Journal of Travel Research 37, 48-55.

May, J.A., Bastian, C.T., Taylor, D.T. and Whipple, G.D. (2001) Market segmentation of Wyoming snowmobilers. Journal of Travel Research 39, 292-299.

Mo, C., Howard, D.R. and Havitz, M.E. (1993) Testing an international tourist role typology. Annals of Tourism Research 20, 319-335.

Moscardo, G., Pearce, P., Morrison, A., Green, D. and O’Leary, J.T. (2000) Developing a typology for understanding visiting friends and relatives markets. Journal of Travel Research 38, 251-259.

Murphy, P.E. (1985) Tourism: A Community Approach. London: Routledge.

National Parks Division (1995) Number of visitors in national parks of Thailand 1990-1995. Bangkok: Unpublished data.

Orams, M.B. (2000) Tourists getting close to whales, is it what whale-watching is all about? Tourism Management 21,561-569.

Palacio, V. and McCool, S.F. (1997) Identifying ecotourists in Belize through benefit segmentation: A preliminary analysis. Journal of Sustainable Tourism 5 (3), 234-243.

Pearce, P.L. (1985) A systematic comparison of travel-related roles. Human Relations 38 (11), 1001-1011.

Perreault, W.D., Darden, D.K. and Darden, W.R. (1977) A psychographic classification of vacation life styles. Journal of Leisure Research 9, 208-224.

Plog, S.C. (1972) Why destination areas rise and fall in popularity. Paper presented at Southern California Chapter of the Travel Research Association.

Sharpley, R. (1994) Tourism, Tourists and Society. Huntingdon: ELM Publications.

Shoemaker, S. (2000) Segmenting the mature market: 10 years later. Journal of Travel Research 39, 11-26.

Smith, V.L. (1977) Hosts and Guests: The Anthropology of Tourism. Philadelphia: University of Pennsylvania Press.

Smith, S.L.J. (1990) A test of Plog's allocentric/psychocentric model: Evidence from seven nations. Journal of Travel Research 28 (4), 40-43.

Smith, S.L.J. and Smale, B. (1980)Classification of visitors to agreements for recreation and conservation sites, national parks and related sites. Contact: Journal of Urban and Environmental Affairs 12 (1), 35-52.

Taylor, G.D. (1986) Multi-dimensional segmentation of the Canadian pleasure travel market. Tourism Management 7 (3), 146-153.

Tobias, D. and Mendelsohn, R. (1991) Valuing ecotourism in a tropical rain-forest reserve. Ambio 20 (2), 91-93.

Tourism Authority of Thailand (2001) Thailand Tourism Statistics.Bangkok: Tourism Authority of Thailand (http:/ / www.tourismthailand.org/stat/index.html)

Tourism Authority of Thailand (1997) Policies and Guidelines: Development of Ecotourism (1995-1996) of the Tourism Authority of Thailand. Bangkok: Tourism Authority of Thailand.

Uysal, M. and McDonald, C.D. (1989) Visitor segmentation by trip index. Journal of Travel Research 27 (3), 38-42.

Wall, G. (1993) Towards a tourism typology. In J.G. Nelson, R. Butler and G. Wall (eds) Tourism and Sustainable Development: Monitoring, Planning, Managing (pp. 45-58). Waterloo, ON: Heritage Resources Centre, University of Waterloo.

Wall, G. (1994) Ecotourism: Old wine in new bottles? Trends 31 (2), 4-9. 